\title{
Neogene flora, vegetation and climate dynamics in southeastern Europe and the northeastern Mediterranean
}

\author{
G. JIMENEZ-MORENO ${ }^{1,2,3}$, S.-M. POPESCU ${ }^{1}$, D. IVANOV ${ }^{4} \&$ J.-P. SUC ${ }^{1}$ \\ ${ }^{1}$ Laboratoire PaléoEnvironnement et PaléobioSphère (UMR CNRS 5125), Université Claude \\ Bernard - Lyon 1, 27-43 boulevard du 11 Novembre, 69622 Villeurbanne, France \\ (e-mail: gonzaloj@ugr.es; popescu@univ-lyon1.fr; jean-pierre.suc@univ-lyon1.fr) \\ ${ }^{2}$ Departamento de Estratigrafía y Paleontología, Universidad de Granada, Avda. \\ Fuente Nueva S/N 18002, Granada, Spain \\ ${ }^{3}$ Center for Environmental Sciences \& Education, Box 5694, Northern Arizona University, \\ Flagstaff, AZ 86011USA. (present address) (e-mail: Gonzalo.Jimenez-Moreno@NAU.EDU) \\ ${ }^{4}$ Institute of Botany, Bulgarian Academy of Sciences, Acad. G. Bonchev Str., 23, 1113 Sofia, \\ Bulgaria (e-mail:dimiter@bio.bas.bg)
}

\begin{abstract}
Pollen analysis of Miocene and Pliocene sediments from southeastern Europe and the northeastern Mediterranean is represented in pollen synthetic diagrams based on ecological criteria in order to clearly visualize changes in the composition and structure of the vegetation through time. New pollen data, together with abundant existing palynological information from this area, show a progressive reduction in plant diversity caused by a decrease in the most thermophilous and high-water requirement plants and, on the contrary, an increase in warm-temperate (mesothermic) and seasonal-adapted taxa during the Middle-Late Miocene and Pliocene. At the same time, an increase in high-elevation trees and herbs has been recorded, with a strong augmentation in Artemisia, first in the eastern Mediterranean and later on in the western Mediterranean area. This has been interpreted as a response of the vegetation to global and regional processes, including climate cooling related to the development of the East Antarctic Ice Sheet (EAIS), uplift of regional mountains during Alpine orogenesis and progressive movement of Eurasia towards northern latitudes as a result of the northwards collision of Africa.
\end{abstract}

Pollen analyses dealing with Miocene-Pliocene sediments from the Paratethys are rare. Studies have focused on the Miocene and Pliocene palynology of the Central Paratethys (Petrescu et al. 1989a, b; Planderová 1990; Nagy 1991, 1992, 1999; Petrescu \& Malan 1992) and Turkey (Benda 1971; Benda et al. 1975; Akgün \& Akyol 1999), but the lack of any quantitative information render these analyses limited. However, palynological data, with reliable botanical identification, are available for the Miocene (Ivanov 1995; Ivanov \& Koleva-Rekalova 1999; Palamarev \& Ivanov 2001; Ivanov et al. 2002; Jiménez-Moreno et al. 2005) and the Pliocene (Drivaliari 1993; Drivaliari et al. 1999; Popescu 2001, 2002, 2006; Popescu et al. 2006a, b) of the same region. In these studies, pollen was not used for biostratigraphy but for climatic information, as independent biostratigraphic dating was available (see below). Pollen counts and a statistical treatment of the data were made to obtain reliable information about floral diversity, organization of the vegetation and to better visualize vegetation and climate change.
The geographical position of the studied area, between Africa and Eurasia and between a Mediterranean and temperate climate, makes this region of great interest for palaeobotanic studies. Today, the southeastern part of the area is mainly occupied by steppe vegetation rich in Artemisia (i.e. the central Anatolian steppes), that is the main refuge area of thermophilous plants (mostly along the Turkish coastlines: Zohary 1973; Quézel \& Médail 2003). Alpine tectonics were active during the Neogene, producing uplift of the Carpathians, Dinarides, Balkan, Rhodope and Taurides mountains. Then, important palaeogeographical changes occurred (see below; Rögl 1998; Meulenkamp \& Sissingh 2003; Popov et al. 2004) that may have contributed to the pattern of vegetation distribution seen today.

In this paper, we present a synthesis of palynological data, interpreted vegetation and climate dynamics based on Miocene and Pliocene deposits from Eastern Europe. New sections of Middle and Late Miocene age from this area have been analysed, adding new information to the already

From: Williams, M., Haywood, A. M., Gregory, F. J. \& Schmidt, D. N. (eds) Deep-Time Perspectives on Climate Change: Marrying the Signal from Computer Models and Biological Proxies. The Micropalaeontological Society,

Special Publications. The Geological Society, London, 503-516.

$1747-602 X / 07 / \$ 15.00$ (C) The Micropalaeontological Society 2007. 
published data. Changes in vegetation have been observed from the Langhian to the early Pliocene (16.3-3 Ma). These are mainly related to global climatic changes, in temperature and precipitation, that are linked to atmospheric and palaeogeographic changes that were of significant importance during the Neogene.

\section{Regional setting}

The studied area comprises Neogene basins formed within the Central-Eastern Paratethys Sea. They were generated during the Neogene, like the rest of the basins belonging to the Paratethys, as a product of the collision of the African plate and Eurasia. These basins are delimited by the Carpathians, Balkan, Dinarides and Taurides, occupying parts of Hungary, Romania, Bulgaria, Serbia,
Greece and Turkey (Fig. 1; Kojumdgieva \& Popov 1989; Rögl 1998; Meulenkamp \& Sissingh 2003; Goncharova et al. 2004; Ilyina et al. 2004; Paramonova et al. 2004; Khondkarian et al. 2004a, b). During the Neogene, the Paratethys displayed a long-term trend of decreasing marine influence and a correlative reduction in size with regard to the marine depositional domains. Marine deposition lasted throughout the Early and Middle Miocene up to approximately $12 \mathrm{Ma}$, when uplift caused the sea to retreat from the Pannonian basin complex where a brackish lake formed instead (Rögl 1998). However, during the Early and Middle Miocene, connection between the Mediterranean Sea and the Paratethys existed that allowed for a free marine faunal exchange (Harzhauser et al. 2003). The first impairment of marine connections is evident in the Late Badenian (Early Serravallian)

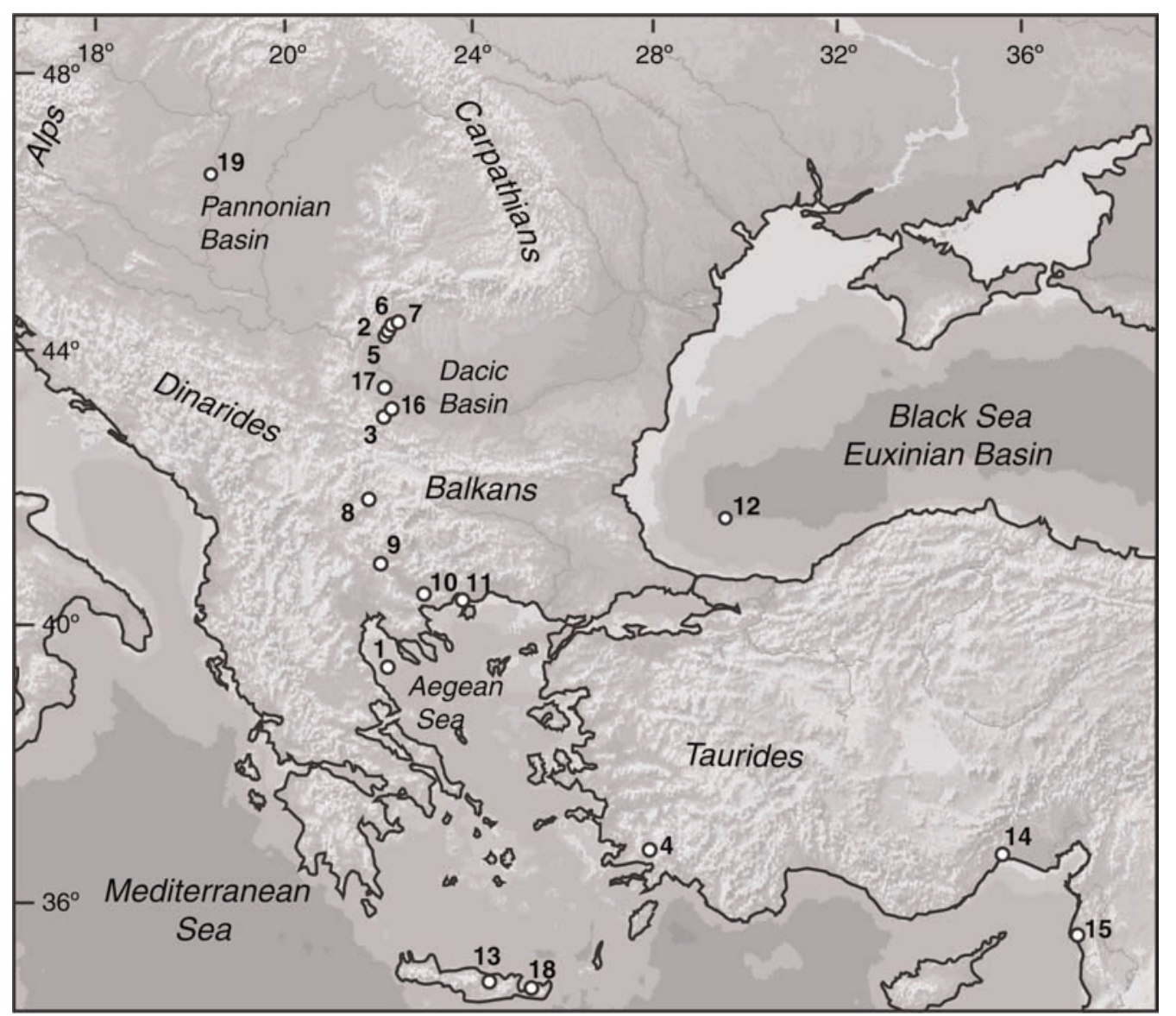

Fig. 1. Geographic map of the studied area and location of the sites. 1 Nireas-1; 2 Valea Morilor; 3 Ruzhintsi; 4 Catakbagyaka; 5 Hinova; Husnicioara and Valea Visenilor; 6 Lupoaia; 7 Ticleni-1; 8 Ravno Pole and Lozenec; 9 Sandanski; 10 Lion of Amphipoli; 11 Nestos-2; 12 Site 380 A; 13 Aghios Vlassios; 14 Avadan; 15 Lataquie; 16 Drenovets C-1; 17 Deleina C-12; 18 Makrilia; 19 Tengelic-2. 
when dysaerobic bottom conditions and a stratified water column characterized the Paratethyan realm (Kovac et al. 2004). With the onset of the Sarmatian, marine connection to the Mediterranean almost completely ceased, and was reflected by the development of a highly endemic molluscan fauna (Harzhauser \& Piller 2004). Finally, at the Sarmatian/Pannonian boundary (Serravallian/Tortonian boundary), the Central Paratethys became entirely restricted and the brackish Lake Pannon was established. Sporadic brief connections occurred during the Late Miocene and Pliocene between the Eastern Paratethys (Dacic and Euxinian basins) and the Mediterranean Sea as documented by nannoplankton influxes (Mărunţeanu \& Papaianopol 1998; Semenenko \& Olejnik 1995). One of these short connections also concerned the southeastern Pannonian Basin during the so-called Portaferrian regional Stage (Pontian). Some of these connections occurred just before and just after the Messinian salinity crisis (Clauzon et al. 2005; Snel et al. 2006), resulting in the same responses (i.e. an intense erosion, then the construction of Gilbert-type fan deltas) to the Messinian desiccation and Zanclean flooding as in the Mediterranean Basin itself (Clauzon et al. 2005). However, during the late Neogene, most of the Paratethyan basins were disconnected and evolved as isolated lakes, some of them being temporarily connected with the Mediterranean Sea (Mărunţeanu \& Papaianopol 1995).

The independent evolution of the different subdomains of the Paratethys led to the construction of several regional stratigraphies, constituted by stages based on diverse groups of organisms, mainly bivalves and ostracods, and benthic and planktonic foraminifera etc. (Marinescu 1978; Papaianopol \& Motas 1978; Papaianopol \& Marinescu 1995; Rögl 1998; Fig. 2). Reliable correlations are established between the Eastern Paratethys regional stratigraphy and the Mediterranean standard stratigraphy using nannoplankton (Papaianopol \& Mărunţeanu 1993; Mărunţeanu \& Papaianopol 1995, 1998; Drivaliari et al. 1999; Clauzon et al. 2005; Snel et al. 2006).

\section{Chronological background}

A total of 19 sections and a total of 680 samples have been studied for pollen. Of those 19 sections, 12 (or a part) belong to the Miocene and 14 (or a part) to the Pliocene (Fig. 2). As far as possible, an independent age control has been obtained; it is indicated in Table 1 with the authors of the pollen analyses. The timescale of Gradstein et al. (2004) has been used.

\section{Methods}

Identification was performed comparing the Neogene pollen grains with those of the living relative plants using databanks of modern pollen grains and modern and past pollen grain photographs. Based on the results of the pollen spectra, standard synthetic diagrams (Suc 1984) with Pinus and Pinaceae have been constructed. In these pollen diagrams, taxa have been arranged into 12 different groups based on ecological criteria in order to obtain some visualization of the vegetation (see below) and more easily compare with reference oxygen isotopic curves. This method has been proven to be a very efficient tool for high-resolution climatic studies characterizing warm-cold alternations related to Milankovitch cycles for both the Miocene (JiménezMoreno et al. 2005) and the Pliocene (Popescu 2001, 2006; Popescu et al. 2006a, b).

Pollen data will be available, after publication, on the web from the 'Cenozoic pollen and climatic values' database (CPC) (http://medias.obs-mip.fr/ cpc).

\section{Results}

\section{Plant diversity and vegetation}

Even if some parts of the studied region are characterized today by a very diverse flora and are main refuge areas of thermophilous plants (i.e. the Ponto-Euxinian area) (Quézel \& Médail 2003), a richer and more diverse flora has been identified for the Mio-Pliocene that consisted of elements found presently in different geographic areas:

(1) Tropical and subtropical Africa, America and Asia (Avicennia, Bombax, Caesalpiniaceae, Engelhardia, Platycarya, Taxodiaceae, Hamamelidaceae, Myrica, Sapotaceae, etc.).

(2) Warm-temperate latitudes of the Northern Hemisphere (Acer, Alnus, Betula, Cupressaceae, Fagus, Populus, deciduous Quercus, Salix, etc.).

(3) Mediterranean region (Olea, Phillyrea, Ceratonia, evergreen Quercus, etc.).

All of these taxa grew in the Eastern European area during the Miocene.

We use the Chinese flora as a present-day comparison for the southeastern Europe and Middle East flora during the Neogene as it is the closest living example of this floral inventory (Suc 1984). Flora of the broad-leaved evergreen forest was represented by 45 typical tropical and subtropical taxa (i.e. megathermic and mega-mesothermic elements, respectively) in the studied region during the middle Miocene's warmest phase; only 21 of them persisted until the early Pliocene and have presently disappeared from the area. Flora of the evergreen and deciduous mixed forest was represented by 21 subtropical and warm-temperate taxa (i.e. mega-mesothermic and mesothermic 


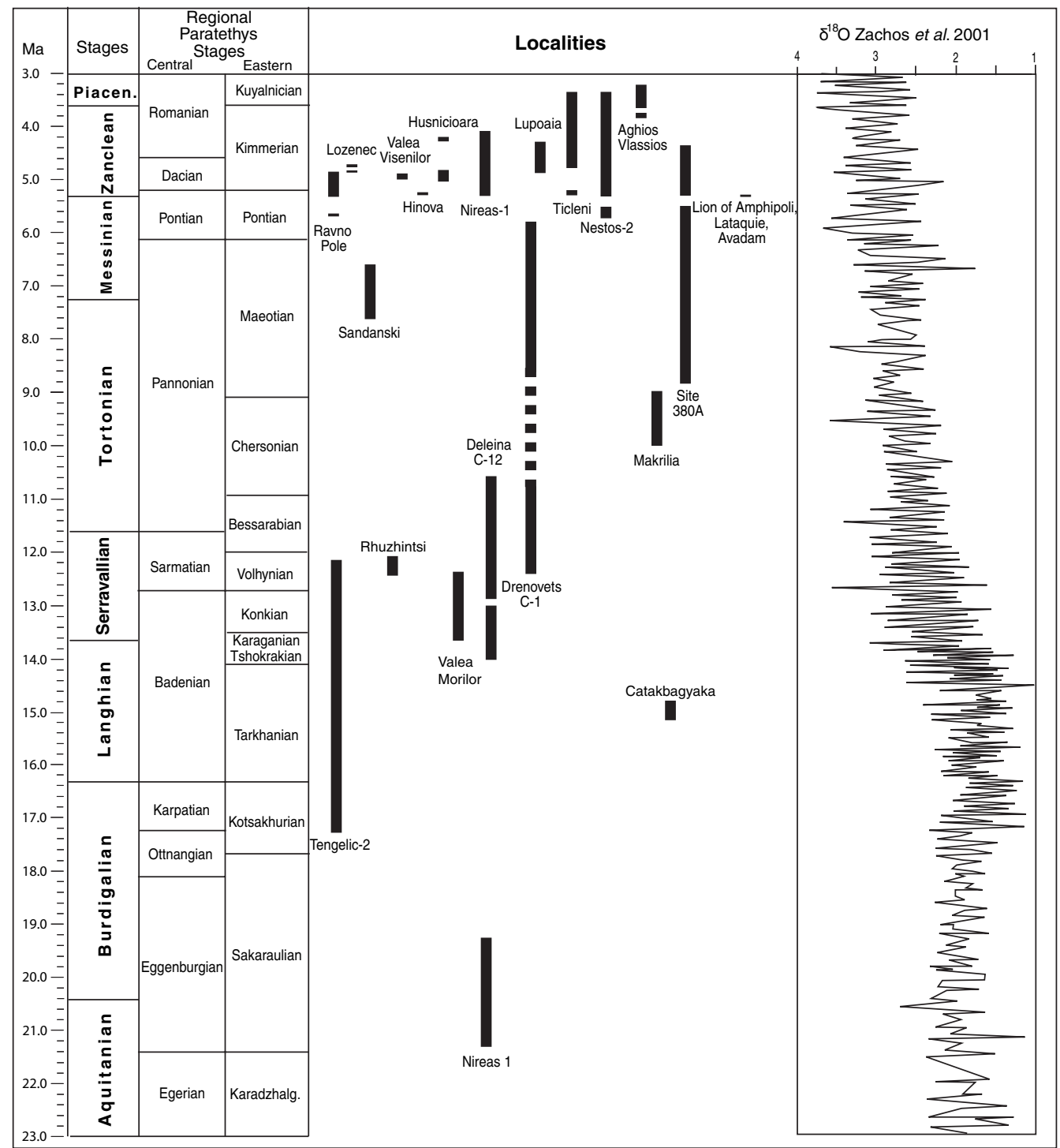

Fig. 2. Miocene and Pliocene chronostratigraphy and temporal situation of the studied sites. Correlations between standard stages and Paratethys stages by Harzhauser \& Piller (in press) after data of Steininger (1999), Sprovieri (1992), Sprovieri et al. (2002), Fornaciari \& Rio (1996) and Fornaciari et al. (1996). Oxygen isotope curve after Zachos et al. (2001); all stages recalibrated according to Gradstein \& Ogg (2004), Gradstein et al. (2004) and Lourens et al. (2004).

elements, respectively) in the studied region during the Middle Miocene's warmest phase; they persisted here during the Early Pliocene and 17 among them are still living in the area.

The vegetation was characterized by a complex mosaic due to its dependency on several factors (water availability, characteristics of the soils, orientation of relief slopes, etc.) which superimposed its latitudinal-altitudinal organization. The most important factor, similar to present day, would be altitude, controlling both temperature and precipitation. Therefore, the vegetation would be organized in altitude belts, which have been compared with those found today in subtropical to temperate southeastern China, the most reliable model. The following have been distinguished:

(1) a coastal marine environment characterized by the presence of an impoverished mangrove composed of Avicennia which is mainly 


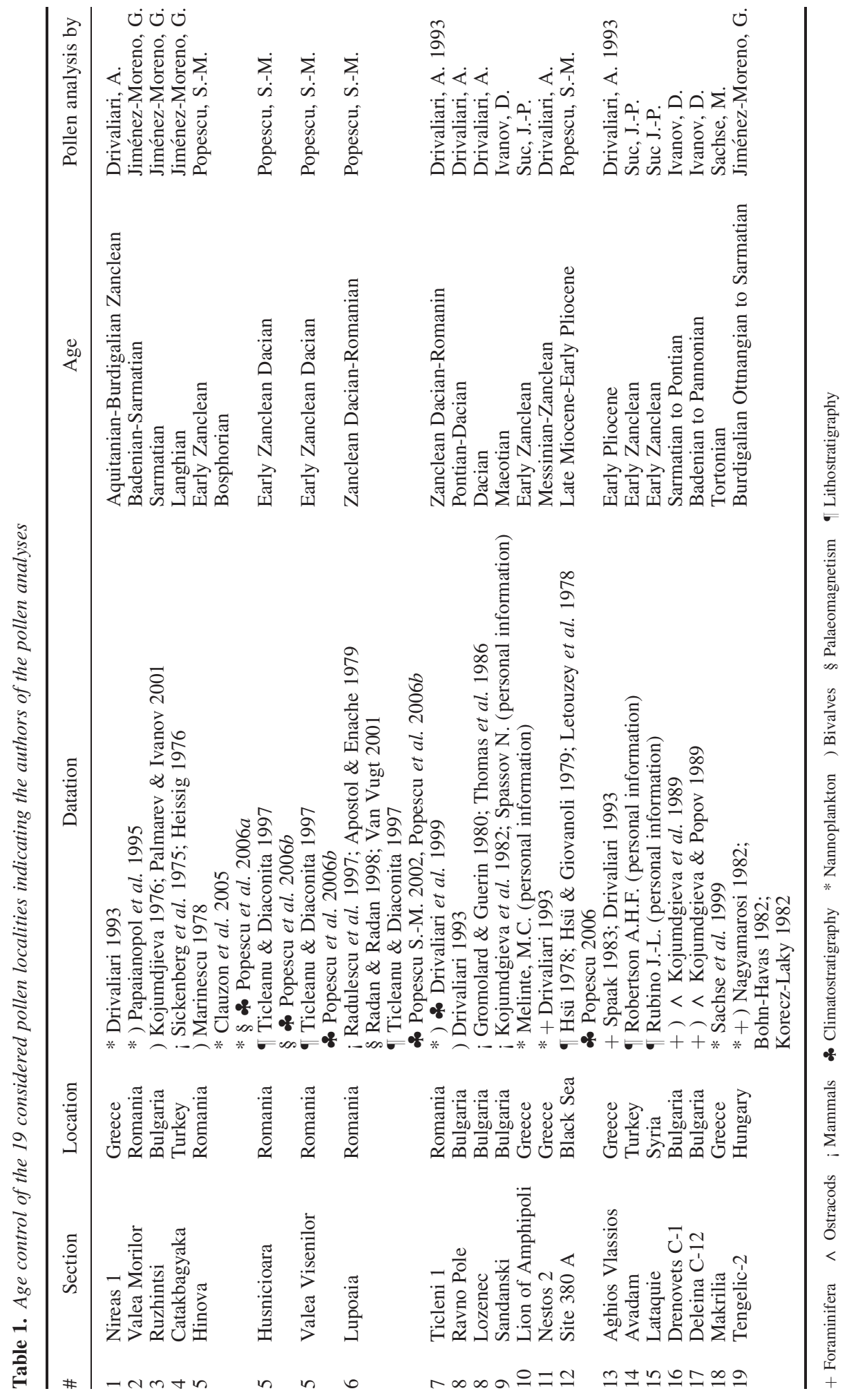


accompanied by halophytes (Amaranthaceae-Chenopodiaceae, Armeria, etc.);

(2) a broad-leaved evergreen forest, from sea level to around $700 \mathrm{~m}$ altitude characterized by Taxodium or Glyptostrobus, Myrica, Rhus, Theaceae, Cyrillaceae-Clethraceae, Bombax, Euphorbiaceae, Distylium, Castanopsis, Sapotaceae, Rutaceae, Mussaenda, Ilex, Hedera, Ligustrum, Jasminum, Hamamelidaceae, Engelhardia, Rhoiptelea, etc.;

(3) an evergreen and deciduous mixed forest, above $700 \mathrm{~m}$ altitude; characterized by deciduous Quercus, Engelhardia, Platycarya, Carya, Pterocarya, Fagus, Liquidambar, Parrotia, Carpinus, Celtis, Acer, etc. Within this vegetation belt, riparian vegetation has been identified, composed of Salix, Alnus, Carya, Carpinus, Zelkova, Ulmus, Liquidambar, etc. The shrub level was dominated by Ericaceae, Ilex, Caprifoliaceae, etc.;

(4) above $1000 \mathrm{~m}$, a mid-altitude deciduous and coniferous mixed forest with Betula, Fagus, Cathaya, Cedrus, Tsuga.

(5) above $1800 \mathrm{~m}$ altitude, a coniferous forest with Abies and Picea.

\section{Vegetation dynamics}

The following description of the Miocene and Pliocene vegetation dynamics in the southern Forecarpathian Basin and Greece-Turkey is a brief summary of the pollen analysis of Drivaliari (1993), Ivanov (1995), Drivaliari et al. (1999), Popescu (2001, 2006), Popescu et al. (2006a, b), JiménezMoreno et al. (2005) and Jiménez-Moreno (2005).

Burdigalian-Langhian (20.4-13.6 Ma). The regular occurrence and abundance of thermophilous species typical of the lowest altitudinal belts described above and the relative scarcity of altitudinal elements (Fig. 3) are characteristic for vegetation of this time. The coastal marine environment was then occupied by an impoverished Avicennia mangrove and several halophytes (Nagy \& Kókay 1991; Nagy 1999; Plaziat et al. 2001; JiménezMoreno 2005). In the hinterland, lowlands were populated by a broad-leaved evergreen forest, characterized by Alchornea, Passifloraceae, Pandanus, Rhus, Theaceae, Cyrillaceae-Clethraceae, Bombax, Rubiaceae, Chloranthaceae, Reevesia, Euphorbiaceae, Distylium, Castanopsis, Sapotaceae, Rutaceae, Mussaenda, Ilex, Hedera, Itea, Alangium, cf. Mastixiaceae, Ligustrum, Jasminum, Hamamelidaceae, Engelhardia, Rhoiptelea, Schizaeaceae, Gleicheniaceae, etc. Within this vegetation belt, swamp forests were also well developed during this time period. Its components, such as Taxodium or Glyptostrobus, Nyssa, Myrica, Planera, show comparatively high values in the pollen spectra. Probably the low elevation palaeogeography and very humid conditions at that time in the studied area favoured the wide distribution of swamp forests and of ecologically related riparian forests with Platanus, Liquidambar, Zelkova, Carya, Pterocarya and Salix.

An evergreen and deciduous mixed forest mainly composed of mesothermic elements such as Quercus, Carya, Pterocarya, Fagus, Ericaceae, Ilex, Caprifoliaceae, Liquidambar, Parrotia, Carpinus, Celtis, Acer, but also Engelhardia, Platycarya, etc., characterized areas of higher altitude. Within this vegetation belt, riparian vegetation has been identified, composed of Salix, Alnus, Carya, Carpinus, Zelkova, Ulmus, etc.

It should also be mentioned that conifer pollen, mainly Pinus and indeterminate Pinaceae, can be particularly abundant, presumably because of the capacity of saccate pollen for long-distance transport (Heusser 1988; Suc \& Drivaliari 1991; Cambon et al. 1997; Beaudouin 2003): during the Badenian, the basin developed its largest extension so that the studied sections had the maximum distance from the coastline (Fig. 3). Mid- and highaltitude elements (Tsuga, Cedrus, Abies and Picea) and Cathaya seem not to vary significantly in sections of this age (Fig. 3).

Serravallian-Tortonian-Messinian (13.6-5.3 $M a$ ). During this time-interval, important changes in the vegetation are observed: Avicennia, which populated the coastal areas in previous times, is not found commonly and several megathermic elements (Buxus bahamensis group, Alchornea, Bombax, Iacacinaceae, Croton, Melastomataceae, etc.), typical from the broad-leaved evergreen forest, became rare and most of them disappeared (Fig. 3). The evergreen-deciduous mixed forest suffered a great transformation due to the loss and decrease in the abundance of several megamesothermic evergreen plants. This kind of vegetation was progressively enriched by deciduous mesothermic plants, such as deciduous Quercus, and Fagus, Alnus, Acer, Eucommia, Betula, Alnus, Carpinus, Ulmus, Zelkova, Tilia, etc. Thus, the vegetation shows a tendency towards increasing proportions of mesothermic deciduous elements coming from higher altitudes.

Even if the thermophilous elements decreased during this period, the swamp forest continued to be well developed. At the same time, the vegetation from mid- (Cathaya, Tsuga and Cedrus) and highaltitude (Picea and Abies) belts clearly strengthened. For instance, Tsuga (mid-altitude indicator) is absent in the Badenian (Langhian and Early Serravallian) or very rare, it is still rare at the base of the Volhynian (approx. 12.7 Ma), but reaches 


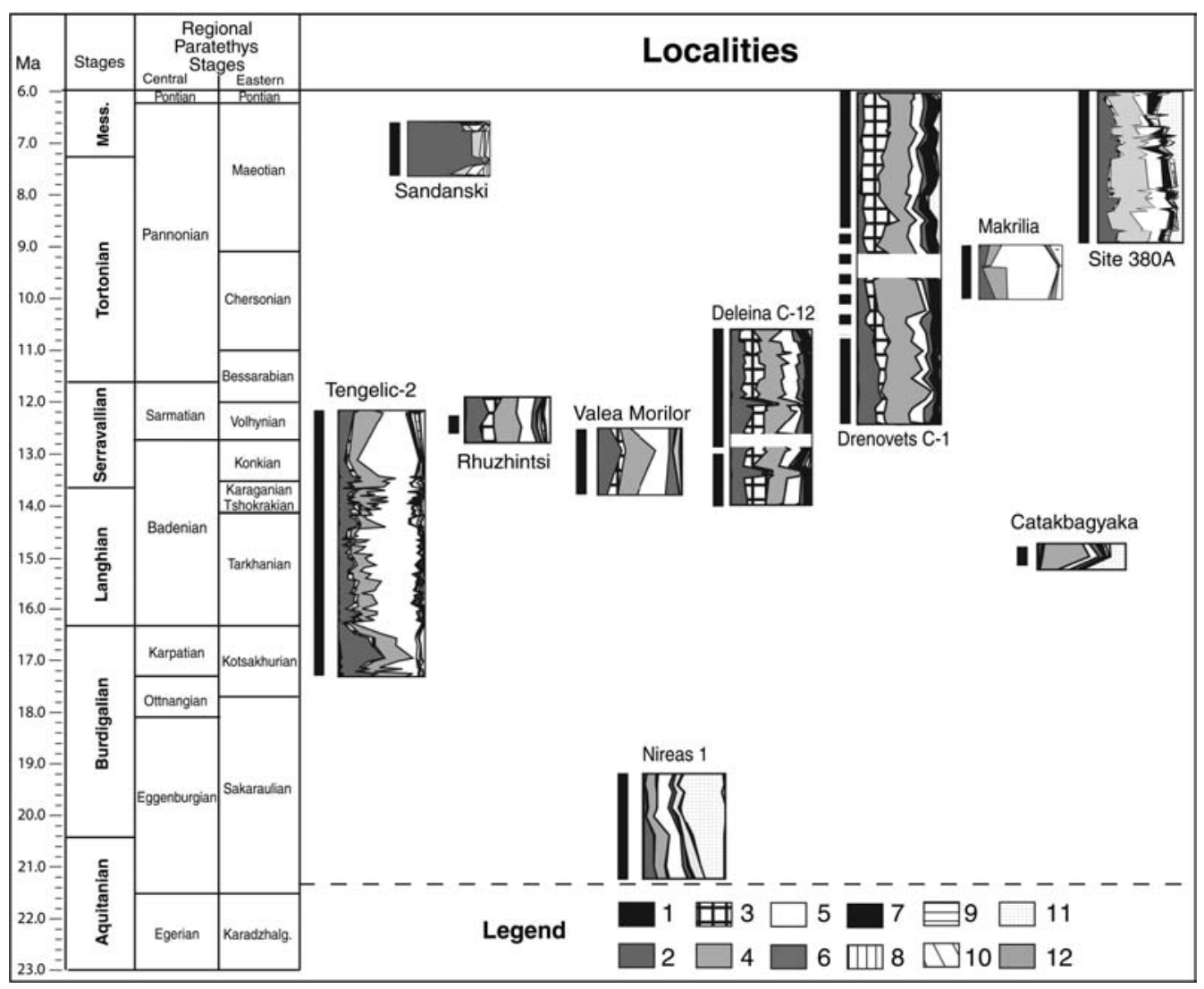

Fig. 3. Synthetic pollen diagrams of the sections spanning the Miocene until $6 \mathrm{Ma}$. Taxa have been grouped according to their ecological significance as follows: 1 Megathermic (= tropical) elements (Avicennia, Amanoa, Alchornea, Fothergilla, Exbucklandia, Euphorbiaceae, Sapindaceae, Loranthaceae, Arecaceae, Acanthaceae, Canthium type, Passifloraceae, etc.). 2 Mega-mesothermic (= subtropical) elements (Taxodiaceae, Engelhardia, Platycarya, Myrica, Sapotaceae, Microtropis fallax, Symplocos, Rhoiptelea, Distylium cf. sinensis, Embolanthera, Hamamelis, Cyrillaceae-Clethraceae, Araliaceae, Nyssa, Liriodendron, etc.). 3 Cathaya, an altitudinal conifer living today in Southern China. 4 Mesothermic (= warm-temperate) elements (deciduous Quercus, Carya, Pterocarya, Carpinus, Juglans, Celtis, Zekkova, Ulmus, Tilia, Acer, Parrotia cf. persica, Liquidambar, Alnus, Salix, Populus, Fraxinus, Buxus sempervirens type, Betula, Fagus, Ostrya, Parthenocissus cf. henryana, Hedera, Lonicera, Elaeagnus, Ilex, Tilia, etc.). 5 Pinus and poorly preserved Pinaceae pollen grains. 6 Meso-microthermic (= mid-altitude) trees (Tsuga, Cedrus). 7 Microthermic (= high-altitude) trees (Abies, Picea). 8 Non-significant pollen grains (undetermined ones, poorly preserved pollen grains, some cosmopolitan or widely distributed elements such as Rosaceae and Ranunculaceae). 9 Cupressaceae. 10 Mediterranean xerophytes (Quercus ilex type, Carpinus cf. orientalis, Olea, Phillyrea, Ligustrum, Pistacia, Ziziphus, Cistus, etc.). 11 Herbs (Poaceae, Erodium, Geranium, Convolvulus, Asteraceae Asteroideae, Asteraceae Cichorioideae, Lamiaceae, Plantago, Euphorbia, Brassicaceae, Apiaceae, Knautia, Helianthemum, Rumex, Polygonum, Asphodelus, Campanulaceae, Ericaceae, Amaranthaceae-Chenopodiaceae, Caryophyllaceae,

Plumbaginaceae, Cyperaceae, Potamogeton, Sparganium, Typha, Nympheaceae, etc.) including some subdesertic elements (Lygeum, Neurada, Nitraria, Calligonum). 12 Steppe elements (Artemisia, Ephedra).

up to $10 \%$ in the middle and upper part of the Volhynian (Fig. 3). This palaeofloristic change occurs slowly and gradually without major fluctuations. A similar vegetation change is observed during the same time-interval in other areas of Europe (e.g. Spain, southern France, Switzerland and Austria: Bessedik 1985; Jiménez-Moreno 2005).
The herbs (mainly Poaceae, AmaranthaceaeChenopodiaceae, Artemisia, Caryophyllaceae, Polygalaceae, Lamiaceae, Asteraceae Asteroideae and Asteraceae Cichorioideae) also became more abundant (Fig. 3). This may be due to a somewhat drier climate during that time as is also indicated by macrofloras of the same area (Palamarev 1991; Palamarev \& 
Ivanov 2004) and confirmed by sedimentological data (Koleva-Rekalova 1994; Ivanov \& Koleva-Rekalova 1999): in Bessarabian to Chersonian sediments (129.1 Ma) of northeast Bulgaria, aragonite sediments occur which are assumed to have been formed under a seasonally dry climate. This trend continued during the Late Miocene. Presumably, open landscapes covered by more xerophytic herbaceous communities existed during that time.

Pliocene (5.3-c. $3.2 \mathrm{Ma}$ ). The vegetation was then characterized by a mosaic of different plant associations inherited from the Miocene. The same vegetation dynamics marked by disappearance of thermophilous plants and increase in mesothermic and micro-mesothermic plants continued. Some of the coastal areas of this region were still inhabited by Avicennia mangrove (Avicennia pollen at Site $380 \mathrm{~A}$ at $781.63 \mathrm{~m}$ ) and several megathermic elements typical from the broad-leaved evergreen forest occupying the lowlands, such as Amanoa, Pachysandra, Entada, Meliaceae, Mimosaceae, Sapindaceae, Tiliaceae, Euphorbiaceae, Acanthaceae and Fothergilla, are sporadically present. They disappeared during the early Pliocene (between $4-3.5 \mathrm{Ma}$ ) (Popescu 2001). The mega-mesothermic plants, belonging to these plant associations, such as Engelhardia, Microtropis, Distylium, Parthenocissus, Sapotaceae, Arecaceae, etc., are still abundant and persisted through the Pliocene (Fig. 4). Swampy (mainly Taxodium or Glyptostrobus, Nyssa, Myrica) and marshy (Cyperaceae, Poaceae, CyrillaceaeClethraceae, Myrica) elements, populating deltaic areas, were very abundant. Trees from the family Taxodiaceae did not disappear from this area until the middle Pleistocene (Mamatsashvili 1975).

The mixed deciduous forest (mainly made up of conifers like Pinus, and several deciduous tress such as Quercus, Acer, Carpinus, Parrotia, Carya, Pterocarya, Liquidambar, Platanus, Tilia, Ulmus, Zelkova, etc.), situated at higher altitude, as well as the trees belonging to the highest altitudinal belts, become more abundant during this period (Cathaya, Cedrus, Tsuga, Picea and Abies) (increasing percentages of these elements are compared on Fig 3 and 4).

Another important fact that makes a difference between the Pliocene and the Miocene is the strong development of the steppe with Artemisia in the Ponto-Euxinian region since the early Pliocene (Site 380A, Fig. 4).

\section{Climatic evolution: regional vs. global climatic change}

The high presence of mega- and mega-mesothermic elements during the Early and early Mid-Miocene suggests the existence of a warm, subtropical climate and a tendency towards slightly cooler conditions in the late Mid-Miocene. Climate was also quite humid, to support the development of such a large association of thermic elements (of presentday 'Asiatic' affiliation and climate) which require very humid conditions all year (Wang 1961). The major change is the impoverishment in plant diversity produced by the disappearance of the most thermophilous plants and the consequent enrichment in mesothermic plants (mainly deciduous Quercus, Alnus, etc.) and high-elevation conifers, from the Serravallian to the Pliocene.

The floral assemblages during the Early and early Mid-Miocene clearly reflect the Miocene Climatic Optimum (MCO: Zachos et al. 2001; Shevenell et al. 2004) well-recorded at Tengelic-2 (Jiménez-Moreno et al. 2005). The major change registered in plant diversity is related to a gradual decrease in temperature and precipitation after the MCO (Ivanov et al. 2002; Jiménez-Moreno et al. 2005). This fact is well documented on a worldwide scale and has been correlated with the general decrease in temperature observed by several authors as a gradual increase in the isotopic $\delta^{18} \mathrm{O}$ values of foraminifera from deep-sea sediments (DSDP Sites 608: Miller et al. (1991) and 588: Zachos et al. (2001)) during this timespan and related to an increase in the size of the EAIS (East Antartic Ice Sheet) (Zachos et al. 2001) (Fig. 2). The isotopic values also indicate that this cooling continued during the Late Miocene and Pliocene (Zachos et al. 2001) (Fig. 2).

High-elevation conifers seem not to vary along the sections of early and early Mid-Miocene; however, these elements are abundant in the samples and indicate that the surrounding mountains were already significantly uplifted. Mid(including Cathaya) and high-elevation conifers clearly increase during the late Mid-Miocene and Late Miocene. This can be observed in the boreholes Deleina C-12 and Drenovets C-1 (Fig. 3).

In addition, an augmentation in herbs, mainly Artemisia, Amaranthaceae-Chenopodiaceae, Poaceae, Asteraceae, etc., during the Late Miocene and Pliocene, indicates more open vegetation, and drier conditions. Supporting this interpretation is the substitution of thermophilous elements with high humidity requirements all year (Asiatic-like vegetation) by mesothermic (mainly deciduous) elements which can survive under seasonal climate with respect to the precipitation (Popescu 2001; Ivanov et al. 2002; JiménezMoreno et al. 2005).

The noticeable increase in mesothermic plants and high-elevation conifers can be interpreted as a result of climate cooling, or by uplift of surrounding mountains (Kuhlemann \& Kempf 2002). In both situations, altitudinal elements would increase. 


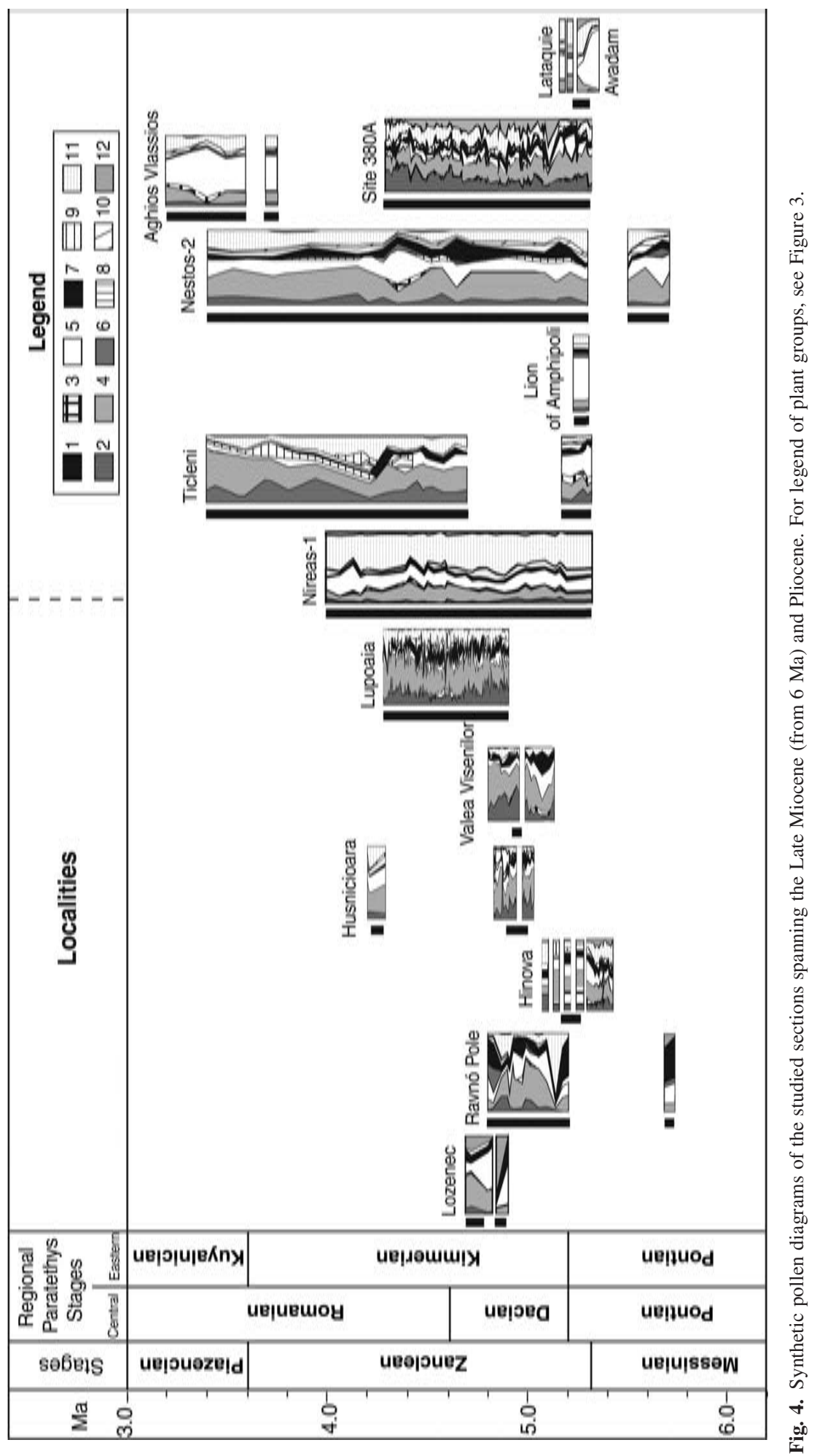


It is quite difficult to separate one process from another (global climatic forcing vs. the regional one), due to the tectonic situation of the studied area and the fact that they may have interfered. However, the vanishing of several thermophilous plants, which lived at low elevations and thus were not affected by the regional uplift, and the climate reconstructions using mainly taxa growing at low to middle-low altitude confirm a decrease in mean annual temperatures (Ivanov et al. 2002; Jiménez-Moreno et al. 2005; Mosbrugger et al. 2005). Then, it is clear that even if the uplift of the surrounding mountains may have influenced the regional climate, the evolution of the vegetation during both the Miocene and Pliocene was very dependent on the global climatic signal as shown in previous studies (Popescu 2001, 2002; Ivanov et al. 2002; Jiménez-Moreno et al. 2005). Hence, according also to the rapid nature of the recorded change in vegetation, we consider that global cooling was the most efficient forcing.

\section{The origin of the steppe with Artemisia}

Open herbaceous formations in the southern Mediterranean area are known since the Burdigalian (Suc et al. 1995a, b; Bachiri Taoufiq et al. 2001; Jiménez-Moreno 2005; Jiménez-Moreno \& Suc in press). They were already well-developed during the Zanclean in other regions of the Mediterranean area (Suc et al. 1999) but were relatively poor in Artemisia. It is at the end of the Pliocene, as the climate got cooler and glacial-interglacial cycles appeared in the Northern Hemisphere, when the steppes with Artemisia became of significant importance (Suc et al. 1995b) during the glacial periods (Suc \& Cravatte 1982; Combourieu-Nebout \& Vergnaud Grazzini 1991; Beaudouin 2003) and even during interglacials (Subally et al. 1999) because of the ambivalent significance of Artemisia from the temperature viewpoint (cold $v s$. warm species: Subally \& Quézel 2002).

The presence of steppe vegetation with Artemisia in the Ponto-Euxinian region (i.e. in Anatolia according to Site 380A pollen record; Popescu 2001, 2006) in the Late Miocene and their significant strengthening in the Early Pliocene is very informative. Their early presence and development in this region, contrary to the extreme scarcity of Artemisia in the Moroccan steppes in the Late Miocene and Early to Middle Pliocene (Bachiri Taoufiq 2000; Suc et al. 1999), indicates that Anatolia and neighbouring areas could have been the source area of this kind of vegetation for the rest of the Mediterranean region, a style of vegetation that became very abundant during the cold periods of the Quaternary (Popescu 2001; Suc \& Popescu
2005). The early settlement and then development of Artemisia steppe vegetation in Anatolia may have resulted from migration from the east of this genus as a consequence of uplift of the Tibetan Plateau (where Artemisia species are still abundant today) and the succeeding reinforced Asiatic monsoon (Zhisheng et al. 2001).

\section{Conclusions}

Pollen data show a progressive reduction in the most thermophilous and high-water requirement plants typical of a broad-leaved evergreen forest and, in contrast, an increase in seasonal-adapted plants coming from higher altitude belts, including mesothermic (mainly deciduous) elements, altitudinal trees and herbs, during the Middle-Late Miocene and Pliocene. This has been interpreted as the response of the vegetation to global climate cooling, accentuated by the regional uplift of the surrounding mountains during Alpine tectonics. This process may also have been favoured by progressive movement of Eurasia towards northern latitudes.

The appearance of steppe vegetation with Artemisia on the Anatolian Plateau since the Late Miocene and its development in the Early Pliocene, significantly earlier than in the rest of Southern Europe, is informative. This suggests that the Anatolian Artemisia-rich steppes could have been the source area of this kind of open vegetal formation for the rest of the Mediterranean area during the Quaternary.

This paper is a contribution to the French Programme 'Environnement, Vie et Sociétés' (Institut Français de la Biodiversité). The authors thank J. Agustí and M. Harzhauser for their helpful reviews, and the EEDEN Programme (ESF) for invitations to participate in international workshops about the subject. Nurdan Yavuz-Isik is thanked for providing the Miocene samples from Turkey.

\section{References}

AKGÜN, F. \& AKYOL, E. 1999. Palynostratigraphy of the coal-bearing Neogene deposits graben in Büyük Menderes Western Anatolia. Géobios, 32, 367-383.

Apostol, L. \& Enache, C. 1979. Etude de l'espèce Dicerorhinus megarhinus (de Christol) du bassin carbonifère de Motru. Travaux du Musée d'Histoire Naturelle "Grigore Antipa", Bucarest, 20, 533-540.

BACHIRI TAOUFIQ, N. 2000. Les environnements marins et continentaux du corridor rifain au Miocène supérieur d'après la palynologie. $\mathrm{PhD}$ thesis, Université Hassan II - Mohammedia, Casablanca (Morocco).

BaChiri TAOUfiQ, N., Barhoun, N., Suc, J.-P., Meon, H., Elaouad, Z. \& Benbouziane, A. 
2001. Environment, végétation et climat du Messinien au Maroc. Paleontologia $i$ Evolució, 32-33, 127-138.

Beaudouin, C. 2003. Effets du dernier cycle climatique sur la vegetation de la basse vallée du Rhône et sur la sédimentation de la plate-forme du golfe du Lion d'après la palynologie. $\mathrm{PhD}$ thesis, Université Claude Bernard Lyon-1, France, 403pp.

BENDA, L. 1971. Grundzüge einer pollenanalytischen Gliederung des türkischen Jungtertiärs. Beihefte zum Geologischen Jahrbuch, 113, 46pp.

Benda, L., Heissig, K. \& Steffens, P. 1975. Die Stellung der vertebraten-faunengruppen der Türkei innerhalb der chronostratigraphischen systeme von Tethys und Paratethys. Geologische Jahrbuch, B, 15, 109-116.

BESSEDIK, M. 1985. Reconstitution des énvironnéments Miocènes de régions nord-ouest méditerranéennes à partir de la palynologie. PhD thesis, Université de Montpellier, France, 162pp.

BoHN-HAVAS, M. 1982. Mollusca fauna of Badenian and Sarmatian stage from the borehole Tengelic 2. In: Nagy, E., Bodor, E., Hagyamarosi, A. ET aL. (eds) Palaeontological examination of the geological $\log$ of the borehole Tengelic 2. Annales Instituti Geologici Publici Hungarici, 65, 200-203.

Cambon, G., Suc, J.-P., Aloisi, J.-C. et al. 1997. Modern pollen deposition in the Rhône delta area (lagoonal and marine sediments) France. Grana, 36, 105-113.

Clauzon, G., Suc, J.-P., Popescu, S.-M., Marunteanu, M., Rubino, J.-L., Marinescu, F. \& Melinte, M. C. 2005. Influence of the Mediterranean sea-level changes over the Dacic Basin (Eastern Paratethys) in the Late Neogene. Basin Research, 17, 437-462.

Combourieu-Nebout, N. \& Vergnaud Grazzini, C. 1991. Late Pliocene Northern hemisphere glaciation: the continental and marine responses in Central Mediterranean. Quaternary Science Reviews, 10, 319-334.

DRIVALIARI, A. 1993. Images polliniques et paléoenvironnement au Néogène supérieur en Méditerranée orientale. Aspects climatiques et paléogéographiques d'un transect latitudinal (de la Roumanie au Delta du Nil). PhD thesis, Université Montpellier-2, France, 333pp.

Drivaliari, A., Ţicleanu, N., Marinescu, F., MăRUnŢEANU, M. \& SUC, J.-P. 1999. A Pliocene climatic record at Ticleni (Southwestern Romania). In: WrenN, J. H., Suc, J.-P. \& Leroy, S. A. G. (eds) The Pliocene: Time of Change. American Association of Stratigraphic Palynologists Foundation, Dallas, 103-108.

ForNACIARI, E. \& Rio, D. 1996. Latest Oligocene to early Middle Miocene quantitative calcareous nannofossil biostratigraphy in the Mediterranean region. Micropaleontology, 42, 1-36.

Fornaciari, E., Di Stefano, A., Rio, D. \& Negri, A. 1996. Middle Miocene quantitative calcareous nannofossil biostratigraphy in the Mediterranean region. Micropaleontology, 42, 37-63.

Goncharova, I. A., SHCHERBA, I. G., KHONDKARIAN, S. O. ET AL. 2004. Lithological-Paleogeographic maps of Paratethys. Map 5: Early Middle Miocene. Courier Forschungsinstitut Senckenberg, 250, 19-21.

Gradstein, F. M. \& OGG, J. G. 2004. Geologic time scale 2004 - why, how, and where next! Lethaia, 37, 175-181.

Gradstein, F. M., OGG, J. G., Smith, A. G., Bleeker, W. \& Lourens, L. J. 2004. A new geologic time scale with special reference to Precambrian and Neogene. Episodes, 27, 83-100.

Gromolard, C. \& Guerin, C. 1980. Mise au point sur Parabos cordieri (de Crystol), un Bovidé (Mammalia, Artiodactyla) du Pliocène d'Europe Occidentale. Géobios, 13, 741-755.

Harzhauser, M., Mandic, O. \& Zuschin, M. 2003. Changes in Paratethyan marine molluscs at the Early/Middle Miocene transition: diversity, palaeogeography and palaeoclimate. Acta Geologica Polonica, 53, 323-339.

Harzhauser, M. \& Piller, W. E. 2004. The Early Sarmatian - hidden seesaw changes. Courier Forschungsinstitut Senckenberg, 246, 89-112.

Harzhauser, M. \& Piller, W. E. in press. Benchmark data of a changing sea - palaeogeography, palaeobiography and events in the Central Paratethys during the Miocene. Palaeogeography, Palaeoclimatology, Palaeoecology

HeIsSIG, K. 1976. Rhinocerotidae (Mammalia) aus der Anchitherium-Fauna Anatoliens. Geologisches Jahrbuch Reihe B, 19, 121pp.

Heusser, L. 1988. Pollen distribution in marine sediments on the continental margin of Northern California. Marine Geology, 80, 131-147.

HsÜ, K. J. 1978. Correlation of Black Sea sequences. In: Ross, D. A., Neprochnov, Y. P. ET AL. (eds) Initial Reports of the Deep Sea Drilling Project, US Government Printing Office, 42, 489-497.

Hsü, K. J. \& Giovanoli, F. 1979. Messinian event in the Black Sea. Palaeogeography, Palaeoclimatology, Palaeoecology, 29, 75-94.

Ilyina, L. B., ShCherba, I. G., KhondKarian, S. O. ET AL. 2004. Lithological-Paleogeographic maps of Paratethys. Map 6: Mid Middle Miocene. Courier Forschungsinstitut Senckenberg, 250, 23-25.

IVANOV, D. 1995. Palynological investigations of Miocene sediments from North-West Bulgaria (in Bulgarian, English abstract). $\mathrm{PhD}$ thesis, Institute of Botany BAS, Sofia, 45pp.

Ivanov, D. A. \& Koleva-ReKalova, E. 1999. Palynological and sedimentological data about Lake Sarmatian palaeoclimatic changes in the Forecarpathian and Euxinian basins (Northern Bulgaria). Acta Paleobotanica, Supplement, 2, 307-313.

IVAnov, D., Ashraf, A. R., Mosbrugger, V. \& Palamarev, E. 2002. Palynological evidence for Miocene climate change in the Forecarpathian Basin (Central Paratethys, NW Bulgaria). Palaeogeography, Palaeoclimatology, Palaeoecology, 178, 19-37.

JiMÉNEZ-MORENO, G. 2005. Utilización del análisis polínico para la reconstrucción de la vegetación, clima y estimación de paleoaltitudes a lo largo de arco alpino europeo durante el Mioceno (21-8 m.a.). PhD thesis, Univ. Granada and Univ. C. Bernard - Lyon 1, 318pp. JiMÉnEZ-MORENO, G., RodríGUEZ-Tovar, F. J., Pardo-Igúzquiza, E., Fauquette, S., Suc, J.-P. 
\& MÜLLER, P. 2005. High resolution palynological analysis in the late early-middle Miocene core from the Pannonian Basin, Hungary: climatic changes, astronomical forcing and eustatic fluctuations in the Central Paratethys. Palaeogeography, Palaeoclimatology, Palaeoecology, 216, 73-97.

JimÉneZ-Moreno, G. \& SUC, J.-P. in press. Middle Miocene Latitudinal Climatic Gradient in Western Europe: Evidence from Pollen Records. Palaeogeography, Palaeoclimatology, Palaeoecology.

Kojumdgieva, E. 1976. Paléoecologie des communautés des mollusques du Miocène en Bulgarie du Nord-Ouest. III. Communautés des mollusques du Volhynien (Sarmatien inférieur). Geologica Balcanica, 6, 53-63.

Kojumdieva, E. \& Popov, N. 1989. Paléogéographie et évolution géodynamique de la Bulgarie Septentrionale au Néogene. Geologica Balcanica, 19, 73-92.

Kojumdgieva, E., Nikolov, I., Nedjalkov, P. \& BusEv, A. 1982. Stratigraphy of the Neogene in the Sandanski Graben. Geologica Balcanica, 12, 69-81.

Kojumdjieva, E., Popov, N., Stancheva, M. \& DaRAKCHIEVA, S. 1989. Correlation of the biostratigraphic subdivision of the Neogene in Bulgaria after molluscs, foraminifers and ostracods. Geologica Balcanica, 19, 9-22.

Koleva-ReKalova, E. 1994. Sarmatian aragonite sediments in North-eastern Bulgaria - origin and diagenesis. Geologica Balcanica, 25, 47-64.

KORECZ-LAKY, I. 1982. Miocene foraminifera fauna from the borehole Tengelic 2. In: NAGY, E., Bodor, E., Hagy amarosi, A. ET AL. (eds) Palaeontological examination of the geological log of the borehole Tengelic 2, Annales Instituti Geologici Publici Hungarici, 65, 186-187.

Kovac, M., Barath, I., Harzhauser, M., Hlavaty, I. \& Hudackova, N. 2004. Miocene depositional systems and sequence stratigraphy of the Vienna Basin. Courier Forschungsinstitut Senckenberg, 246, 187-212.

Kuhlemann, J. \& KempF, O. 2002. Post-Eocene evolution of the North Alpine Foreland Basin and its response to Alpine tectonics. Sedimentary Geology, 152, 45-78.

Letouzey, J., Gonnard, R., Montadert, L., KristcheV, K. \& Dorkel, A. 1978. Black Sea: Geological setting and recent deposits distribution from seismic reflection data. In: Ross, D. A., NeProchnov, Y. P. ET AL. (eds) Initial Reports of the Deep Sea Drilling Project, US Government Printing Office, 42, 1077-1084.

Lourens, L., Hilgen, F., Shackleton, N. J., LASKAR, J. \& WILSON, D. 2004. The Neogene Period. In: Gradstein, F., OgG, J. \& Smith, A. (eds) Geologic Time Scale 2004. Cambridge University Press.

MAMATSASHVILI, N. S. 1975. The palynological characteristics of the Kolkhida Quaternary continental deposits (The Georgian SSR). Metsniereba, Tbilisi, $114 \mathrm{pp}$.

MARINESCU, F. 1978. Stratigrafia Neogenului superior din sectorul vestic al Bazinului Dacic. Editura Academiei Republicii Socialista România (in Romanian), $155 \mathrm{pp}$.
MăRunțEAnU, M. \& PAPAIANOPOL, I. 1995. L'association de nannoplancton dans les dépôts romaniens situés entre les vallées de Cosmina et de Cricovu Dulce (Munténie, bassin dacique, Roumanie). Romanian Journal of Paleontology, 76, 169-170.

MĂRUnŢEANU, M. \& PAPAIANOPOL, I. 1998. Mediterranean calcareous nannoplankton in the Dacic Basin. Romanian Journal of Stratigraphy, 78, 115-121.

Meulenkamp, J. E. \& Sissingh, W. 2003. Tertiary palaeogeography and tectonostratigraphic evolution of the Northern and Southern Peri-Tethys platforms and the intermediate domains of the African-Eurasian convergent plate boundary zone. Palaeogeography, Palaeoclimatology, Palaeoecology, 196, 209-228.

Miller, K. G., Feigenson, M., Wright, J. D. \& Clement, B. 1991. Miocene isotope reference section, Deep Sea Drilling Project Site 608: an evaluation of isotope and biostratigraphic resolution. Palaeoceanography, 6, 33-52.

Mosbrugger, V., Utescher, T. \& Dilcher, D. L. 2005. Cenozoic continental climatic evolution of Central Europe. PNAS, 102, 14964-14969.

NAGY, E. 1991. Climatic changes in the Hungarian Neogene. Review of Palaeobotany and Palynology, 65, 71-74.

NAGY, E. 1992. Magyarorszag Neogen sporomorphainak ertekelese. Geologica Hungarica, 53, 1-379.

NAGY, E. 1999. Palynological correlation of the Neogene of the Central Paratethys. Geological Institute of Hungary, Budapest, 149pp.

Nagy, E. \& KóKAY, J. 1991. Middle Miocene mangrove vegetation in Hungary. Acta geologica Hungarica, 34, $45-52$.

NAGYMAROSI, A. 1982. Badenian-Sarmatian nannoflora from the borehole Tengelic 2. In: NAGY, E., Bodor, E., Hagyamarosi, A. ET AL. (eds) Palaeontological examination of the geological log of the borehole Tengelic 2, Annales Instituti Geologici Publici Hungarici, 65, 145-149.

Palamarev, E. 1991. Composition, structure and main stages in the evolution of Miocene paleoflora in Bulgaria. Dsc thesis, (in Bulgarian). BAS, Sofia, 60pp.

Palamarev, E. \& IVAnov, D. 2001. Charakterzüge der vegetation des Sarmatien (Mittlel- bis Obermiozän im südlichen Teil des Dazischen Beckens (Südost Europa). Palaeontographica, B259, 209-220.

Palamarev, E. \& IVAnOv, D. 2004. Badenian vegetation of Bulgaria: biodiversity, palaeoecology and palaeoclimate. Courier Forschungsinstitut Senckenberg, 249, 63-69.

PAPAIANOPOL, I. \& MĂRUNŢEANU, M. 1993. Biostratigrapy (molluscs and calcareous nannoplankton) of the Sarmatian and Meotian in eastern Muntenia (dacic basin-Rumania), Zemni plyn a nafta, 38, 9-15.

PAPAIANOPOL, I. \& MARINESCU, F. 1995. Lithostratigraphy and age of Neogene deposits on the Moesian Platform, between Olt and Danube Rivers. Romanian Jornal of Stratigraphy, 76, 67-70.

PAPAIANOPOL, I. \& MOTAS, I. C. 1978. Marqueurs biostratigraphiques pour dépôt post-chersoniens du Bassin Dacique. Dari de Seama ale Institutului de Geologie si Geofizica, Stratigrafie, 64, 283-294.

PAPAIANOPOL, I., JiPA, D., MARINESCU, F., ŢIClEANU, N. \& Macalet, R. 1995. Upper Neogene from the 
Dacic Basin - Guide to excursion B2 (post-congress) $\mathrm{X}$ congress RCMNS, Bucuresti. Romanian Journal of Stratigraphy, 76, 1-43.

Paramonova, N. P., Shcherba, I. G. \& KhondaKarIAN, S. O. 2004. Lithological-Paleogeographic maps of Paratethys. Map 7: Late Middle Miocene (Late Serravallian, Sarmatian s.s., Middle Sarmatian s.1.). Courier Forschungsinstitut Senckenberg, 250, 27-31.

Petrescu, I. \& Malan, L. 1992. Contributions to the knowledge of Upper Neogene microflora East of Turnu-Severin (Summary). Univ. Babes-Bolyai, ClujNapoca Gradina Botanica, Contributii Botanice 1991-1992: 135-143.

Petrescu, I., Cernita, P., Meilescu, C. et al. 1989a. Preliminary approaches to the palynology of the Lower Pliocene (Dacian) deposits in the Husnicioara area (Mehedinti county, SW Romania). Studia Universitatis Babes-Bolyai Geologia-Geografia, 34, $67-74$.

Petrescu, I., Nica, T., Filipescu, S. et al. $1989 b$. Paleoclimatical significance of the palynlogical approach to the Pliocene deposits of Lupoaia (Gorj county). Studia Univeritatis Babes-Bolyai GeologiaGeografia, 34, 75-81.

Planderová, E. 1990. Miocene microflora of slovak Central Paratethys and its biostratigraphical significance. Dionyz Stur Institute of Geology, Bratislava (Slovakia), 143pp.

Plaziat, J.-C., Cavagnetto, C., Koeniguer, J.-C. \& BALTZER, F. 2001. History and biogeography of the mangrove ecosystem, based on a critical reassessment of the paleontological record. Wetlands Ecology and Management, 9, 161-179.

POPESCU, S.-M. 2001. Végetation, climat et cyclostratigraphie en Paratéthys centrale au Miocène supérieur et au Pliocène inférieur d'après la palynologie. $\mathrm{PhD}$ thesis. Université Claude Bernard Lyon-1, Lyon, France.

PopesCU, S.-M. 2002. Repetitive changes in Early Pliocene vegetation revealed by high-resolution pollen analysis: revised cyclostratigraphy of southwestern Romania. Review of Palaeobotany and Palynology, 120, 181-202.

PoPeSCU, S.-M. 2006. Upper Miocene and Lower Pliocene environments in the southwestern Black Sea region from high-resolution palynology of DSDP site 380A (Leg 42B). Palaeogeography, Palaeoclimatology, Palaeoecology, 238, 64-77.

Popescu, S.-M., KRIJgSMan, W., Suc, J.-P., Clauzon, G., Marunteanu, M. \& NicA, T. 2006a. Pollen record and integrated high-resolution chronology of the early-Pliocene Dacic Basin (Southwestern Romania). Palaeogeography, Palaeoclimatology, Palaeoecology, 238, 78-90.

Popescu, S.-M., SuC, J.-P. \& Loutre, M.-F. $2006 b$. Early Pliocene vegetation changes forced by eccentricity-precession. Example from Southwestern Romania. Palaeogeography, Palaeoclimatology, Palaeoecology, 238, 340-348.

Popov, S. V., Rögl, F., Rozanov, A. Y., Steininger, F. F., Shcherba, I. G. \& Kovac, M. (eds) 2004. Lithological-Paleogeographic maps of Paratethys. 10 maps Late Eocene to Pliocene. Courier Forschungsinstitut Senckenberg, 250, 1-46.
QUÉZEL, P. \& MÉDAIL, F. 2003. Ecologie et biogéographie des forêts du bassin méditerranéen, Elsevier France, $571 \mathrm{pp}$.

RADAN, S. C. \& RADAN, M. 1998. Study of the geomagnetic field structure in the Tertiary in the context of magnetostratigraphic scale elaboration. I - The Pliocene. An. Inst. Geol. Rom., 70, 215-231.

Radulescu, C., SAmson, P.-M., Sen, S., Stiuca, E. \& HoROI, V. 1997. Les micromammifères pliocènes de Deanic (bassin Dacique, Roumanie). In: Aguilar, J.-P., Legendre, S. \& Michaux, J. (eds) BiochroM'97, Mémoires Travaux E.P.H.E., Institute Montpellier, 21, 635-647.

RöGL, V. F. 1998. Palaeogeographic considerations for Mediterranean and Paratethys seaways (Oligocene to Miocene), Annalen des Naturhistorischen Museums in Wien, 99A, 279-310.

Sachse, M., Mohr, B. \& Suc, J.-P. 1999. The Makrilaflora (Crete, Greece) - a contribution to the Neogene history of the climate and vegetation of the Eastern Mediterranean. Acta palaeobotanica, Supplement 2, $365-372$.

Semenenko, V. N. \& OLEJNIK, E. S. 1995. Stratigraphic correlation of the Eastern Paratethys Kimmerian and Dacian stages by molluscs, dinocyst and nannoplankton data. Rom. J. Stratigraphy, 76, 113-114.

Shevenell, A. E., Kennett, J. P. \& LeA, D. W. 2004. Middle Miocene southern cooling and Antarctic cryosphere expansion. Science, 305, 1766-1770.

Sickenberg, O., Becker-Platen, J. D., Benda, L. ET AL. 1975. Die Gliederung des höheren Jungtertiärs und Altquartärs in der Türkei nach Vertebraten und ihre Bedeutung für die inernationale Neogen-Stratigraphie. Geologisches Jahrbuch Reihe B, 15, 167pp.

Snel, E., Mărunțeanu, M., Macalet, R., MeulenKAMP, J. E. \& VAN VUGT, N. 2006. Late Miocene to Early Pliocene chronostratigraphic framework for the Dacic Basin, Romania. Palaeogeography, Palaeoclimatology, Palaeoecology, 238, 107-124.

SPAAK, P. 1983. Accuracy in correlation and ecological aspects of the planktonic foraminiferal zonation of the Mediteranean Pliocene. Utrecht Micropalaeontological Bulletin, 28, 160pp.

Sprovieri, R. 1992. Mediterranean Pliocene biochronology: a high resolution record based on quantitative planktonic foraminifera distribution. Rivista Italiana di Paleontologia e Stratigrafia, 98, 61-100.

Sprovieri, R., Bonomo, S., CARUso, A. ET AL. 2002. An Integrated calcareous plankton biostratigraphic scheme and biochronology of the Mediterranean Middle Miocene. Rivista Italiana di Paleontologia e Stratigrafia, 108, 337-353.

Steininger, F. F. 1999. Chronostratigraphy, Geochronology and Biochronology of the "European Land Mammal Mega-Zones" (ELMMZ) and the Miocene "Mammal-Zones" (MN-Zones). In: RösSNER, G. E. \& Heissig, K. (eds) The Miocene Land Mammals of Europe. Dr. Friedrich Pfeil, München, Germany, 9-24.

Subally, D., Billodeau, G., Tamrat, E., Ferry, S., Debard, E. \& Hillaire-Marcel, C. 1999. Cyclic climatic records during the Olduvai subchron (uppermost Pliocene) on Zakynthos Island (Ionian Sea). Geobios, 32, 793-803. 
Subally, D. \& QuÉzel, P. 2002. Glacial or interglacial: Artemisia a plant indicator with dual responses. Review of Palaeobotany and Palynology, 120, $123-130$.

SuC, J.-P. 1984. Origin and evolution of the Mediterranean vegetation and climate in Europe. Nature, 307, 429-432.

SuC, J.-P. \& CRAVATte, J. 1982. Etude palynologique du Pliocène de Catalogne (nord-est de l'Espagne). Paléobiologie Continentale, 13, 1-31.

Suc, J.-P. \& DRIVAliari, A. 1991. Transport of bisaccate coniferous fossil pollen grains to coastal sediments: an example from the earliest Pliocene Orb Ria (Languedoc, Southern France). Review of Palaeobotany and Palynology, 70, 247-253.

SuC, J.-P. \& POPESCU, S.-M. 2005. Pollen records and climatic cycles in the North Mediterranean region since 2.7 Ma. In: HEAD, M. J. \& GIBBARD, P. L. (eds) Early-Middle Pleistocene Transitions: The Land-Ocean Evidence. Geological Society of London, Special Publication, 247, 147-158.

SuC, J.-P., DiNIZ, F., LEROY, S. ET AL. 1995a. Zanclean $(\sim$ Brunssumian) to early Piacenzian $(\sim$ early-middle Reuverian) climate from $4^{\circ}$ to $54^{\circ}$ north latitude (West Africa, West Europe and West Mediterranean areas). Mededelingen Rijks Geologische Dienst, 52, 43-56.

Suc, J.-P., Bertini, A., Comborieu-Nebout, N. ET AL. 1995b. Structure of West Mediterranean vegetation and climate since 5.3 Ma. Acta zoologica Cracoviense, 38, 3-16.

Suc, J.-P., FAuquette, S., BessediK, M. et al. 1999. Neogene vegetation changes in West European and West circum-Mediterranean areas. In: AgUsTí, J.,
ROOK, L. \& ANDREWS, P. (eds) The Evolution of Neogene Terrestial Ecosystems in Europe. Cambridge University Press, Cambridge, 378-388.

Thomas, H., Spassov, N., Koduumueva, E. ET al. 1986. Résultats préliminaires de la première mission paléontologique franco-bulgare à Dorkovo (arrondissement de Pazardjik, Bulgarie). Comptes Rendus de ĺAcademie des Sciences, Paris, 302, 1037-1042.

Ticleanu, N. \& Diaconita, D. 1997. The main coal facies and lithotypes of the Pliocene coal basin, Oltenia, Romania. In: GAYER, R. \& PESEK, J. (eds) European Coal Geology and Technology, Geological Society, London, Special Publication, 125, 131-139.

Van Vugt, N., Langereis, C. G. \& Hilgen, F. J. 2001. Orbital forcing in Pliocene-Pleistocene Mediterranean lacustrine deposits: dominant expression of eccentricity versus precession. Palaeogeography, Palaeoclimatology, Palaeoecology, 172, 193-205.

WANG, C. W. 1961. The forests of China with a survey of grassland and desert vegetation. Maria Moors Cabot Foundation, 5, Harvard University Cambridge, Massachusetts, 313pp.

Zachos, J., Pagani, M., Sloan, L. \& Billups, K., 2001. Trends, rhythms, and aberrations in global climate 65 Ma to present. Science, 292, 686-693.

Zhisheng, A., KutzBach, J., Prell, W. L. \& Porter, S. C. 2001. Evolution of Asian monsoons and phased uplift of the Himalaya-Tibetan plateau since Late Miocene times. Nature, 411, 62-66.

ZOHARY, M. 1973. Geobotanical foundations of the Middle East. Fischer ed., Stuttgart, 2 vol., 739pp. 